\title{
Positioning Open Access Journals in a LIS Journal Ranking
}

\section{Jingfeng Xia}

This research uses the $\mathrm{h}$-index to rank the quality of library and information science journals between 2004 and 2008. Selected open access (OA) journals are included in the ranking to assess current $O A$ development in support of scholarly communication. It is found that $O A$ journals have gained momentum supporting high-quality research and publication, and some OA journals have been ranked as high as the best traditional print journals. The findings will help convince scholars to make more contributions to OA journal publications, and also encourage librarians and information professionals to make continuous efforts for library publishing.

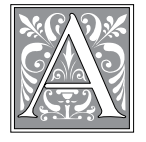

ccording to the Budapest Open Access Initiatives, open access (OA) denotes "its free availability on the public internet, permitting any users to read, download, copy, distribute, print, search, or link to the full texts of these articles, crawl them for indexing, pass them as data to software, or use them for any other lawful purpose, without financial, legal, or technical barriers other than those inseparable from gaining access to the internet itself." 1 Therefore, an OA journal is referred to as one that is freely available online in full text. Conversely, a non-OA journal is one that needs subscription and thus is not freely available. ${ }^{2}$ There are scholarly journals that were subscriptionbased but are later converted to OA. ${ }^{3}$

Academic journal ranking serves as an important criterion for the scholarly community to assess research quality and for librarians to select the best publications for collection development. Because of the complexity of publication behaviors, various approaches have been developed to assist in journal ranking, of which comparing the rates of citation using citation indexes to rate journals has been popularly practiced and recognized in most academic disciplines. ISI's Journal Citation Reports (JCR) is among the most used rankings, which "offers a systematic, objective means to critically evaluate the world's leading journals, with quantifiable, statistical information based on citation data." 4 Yet, citation-based journal rankings, such as JCR, have included few open access journals on their lists. Of these limited OA journals, many were either recently converted into open access or are publicly available with conditions. The relative exclusion of OA journals creates two deficiencies for scholarly communication. First, these rankings may not accurately portray the full picture of journal publications to reflect an ongoing advancement in scholarship. Second, they

Jingfeng Xia is Assistant Professor in the School of Library and Information Science at Indiana University; e-mail: xiaji@iupui.edu. The author is grateful to Professor Debora Shaw for her help. (C) Jingfeng Xia Attribution-NonCommercial (http://creativecommons.org/licenses/by-nc-sa/3.0/) CC BY-NC 
may discourage the open access movement by marginalizing the majority of OA journals. In fact, some OA journals have successfully built reputations, attracting high-quality articles and sizable numbers of citations. This research is an attempt to add selected OA journals to the journal quality rankings using library and information science (LIS) as an example. It is helpful to detect the position of OA journals in journal rankings so that scholars can recognize the progresses of OA publishing and make active contributions to support the OA movement. Such rankings will also encourage librarians and information professionals to improve the existing library publishing enterprise and make continuous efforts for journal practices.

\section{Background}

In a series of articles, Mukherjee reports his studies on a group of 17 fully open access LIS journals published in the period of 2000-2004..$^{5}$ By calculating the citation rates of research papers in these journals, he uses journal impact factors and other indexes to evaluate their contribution to scholarship. The impact factors and total citation counts are matched to those available in JCR for traditional LIS journals in the same time span, with results indicating that some LIS OA journals have an impact comparable with JCR journals. To be specific, "the actual number of Web citations in the case of some of these for at least seven OA journals was a bit lower than ISI's high-ranked LIS journals, but much higher than median-ranked journals." ${ }^{6}$ His study is representative of the very few investigations that have tried to position OA journals in scholarly journal rankings. Yet the problem of Mukherjee's research is that he attempts to manipulate a simple comparison between two sets of data from different citation data services: one from ISI's Web of Science (WoS) and the other from Google Scholar (GS). A high degree of correlation between indexes of these two databases, as discovered by Meho and Yang, ${ }^{7}$ does not necessarily ensure the validity of a direct match between the absolute numbers. For absolute numbers, GS returns more citations than both Scopus and WoS databases. ${ }^{8}$

An easy solution is to calculate the citation indexes of both OA and non-OA journals from the same data source. WoS citation records do not allow direct comparison because many OA journal articles are not included; however, GS offers a good dataset with which to work. Many studies have measured the quality of GS searches and the similarities between WoS and GS. ${ }^{9}$ The correlation between datasets from the two sources is consistently found to be significant. Additional studies also recognize GS as a reliable citation provider for bibliometric work, ${ }^{10}$ particularly for the retrieval of OA article citations. ${ }^{11}$ Furthermore, GS returns more citations from conference papers, books, and dissertations/theses, which show evidence of wider scholarly impact. There are some disadvantages of using GS for citation analyses. For example, GS's data coverage is better for certain academic fields (such as social sciences, arts, and humanities) where books and conference papers constitute a large part of formal publications. ${ }^{12}$ Also, due to the short history of GS, its database contains fewer citations for old publications. ${ }^{13}$ However, these limitations will not affect our use of GS for OA journal ranking because this analysis is based on new data from 2004 to 2008 and within a single discipline.

Instead of relying on journal impact factors to compare OA journals, this analysis adopts the $h$-index approach for journal ranking. The $h$-index is an improvement over simple citation measures, emphasizing the total number of citations or publications, and it works properly for comparing publications in the same field. ${ }^{14}$ Since first proposed in 2005, its benefits of quantifying the impact of research outcomes have been widely recognized. Studies show that for citation analyses at the article level, "the Spearman rank order correlation between citation ranks and $h$-index 
(with self-citations excluded) was 0.9, significant at the 0.01 level" $^{\prime \prime} ;$ and, at the journal level, "the Spearman correlation between the ISI JIF and the $h$-index-used because both the JIF and $h$-index have non-normal distributions - is strong and very significant: $0.718(\mathrm{p}<0.000) .{ }^{\prime 16}$ The $h$-index is especially known for its robust performance and its combined effect for both quantity (number of publications) and quality (citation rate) in a balanced way. ${ }^{17}$ The fact that the $h$-index works well for the calculation of journal citations for a definite period makes it an appropriate measure for OA journal analysis in this research.

Various studies have tested the $h$-index and its value in assessing journal impact in some academic fields. For example, by using the evidence of convergent and discriminatory validity, Hodge suggests the real utility of the $h$-index for social work journals and points to "its compatibility with the profession's applied research culture and its ability to be used with essentially all journals in which social workers publish." ${ }^{18}$ Harzing and van der Wal apply the $h$-index to assess journal impact in the field of economics and business and realize its advantages for a more accurate and comprehensive measure of journal impact. ${ }^{19}$ With a discovered strong correlation between a journal's impact factor and its quality, ${ }^{20}$ we are confident of the application of the $h$-index in OA journal assessment.

\section{Methods}

In this research, both OA and non-OA LIS journals from 2004 to 2008 were combined for an $h$-index analysis to position OA journals in the journal ranking. The selection of this time frame was based on the consideration that many OA journals were launched before the new millennium and thus had time to establish their reputations by the mid-2000s. This time frame also allowed a window for journals published as late as 2008 to receive citations. A group of 85 core LIS journals was assembled from the following sources:
- JCR's collection of 61 journals, which are considered to represent the core journals in LIS by ISI, in its "Information Science \& Library Science" category of the 2008 edition.

- Nisonger and Davis' list of journals, rated by LIS education deans and ARL library directors, to supplement the journal list in JCR. ${ }^{21}$

- Directory of Open Access Journals collection of a total of 116 OA journals in LIS, retrieved at the end of $2010 .^{22}$

- Mukherjee's list of 17 OA journals, which are freely accessible in full text and represent a group of core OA LIS journals in the data selection.

JCR's list served as the basic collection of LIS journals, which was re-evaluated and also supplemented by adding relevant journals from other sources listed above. The following criteria were used for the journal selection.

- Journals not published in English were removed because both GS and WoS databases do not properly handle names with diacritics, which are common in many other languages.

- OA journals with initial publications after 2004 were removed to give every journal the same time period to accrue citations. Exceptions include journals that were originally published in print and converted to open access after 2004.

- Non-peer-reviewed journals were removed. The decision was based on manual inspections of journal articles that are not research in nature. Such journals are American Libraries, EContent, Information Outlook, Library Journal, Online, Public Libraries, School Library Journal, and The Scientist.

In this research, several journals are subscription-based but become open access after an embargo period of various lengths. For example, Information Technology $\mathcal{E}$ Libraries has a six-month embargo period, and Learned Publishing opens its articles to the public a year after they are published. A complete list of these conditional OA journals is available in table 1 . The different lengths of OA embargo pe- 


\begin{tabular}{|l|l|}
\hline \multicolumn{2}{|c|}{ TABLE 1 } \\
Journals with Conditional Open Access \\
\hline Journal & $\begin{array}{c}\text { Embargo } \\
\text { Period }\end{array}$ \\
\hline American Archivist & 3 Years \\
\hline College \& Research Libraries* & 6 Months \\
\hline Health Information and Libraries Journal & 3 Years \\
\hline Information Technology and Libraries & 6 Months \\
\hline Learned Publishing & 1 Year \\
\hline Library Resources \& Technical Services & 1 Year \\
\hline LIBRI & 1 Year \\
\hline Research Evaluation & 2 Years \\
\hline $\begin{array}{l}\text { * College \& Research Libraries became an OA journal from } \\
\text { Spring 2011 }\end{array}$ \\
\hline
\end{tabular}

riod may have an impact on the citation accumulation - the longer the embargo period, the fewer the opportunities a journal has had for people to access its articles published during the period of 2004-2008. Some of these journals moved toward OA after 2004, making the situation even more complicated. Yet, due to the small number of such journals, the differences were negligible in the ranking. In the analysis, these embargoed journals are clearly listed as "conditional" to separate them from either OA or nonOA journals.

Many journals, such as Journal of Education for Library $\mathcal{E}$ Information Science, made featured articles or even an occasional entire issue open access as a marketing strategy. Because their OA rate was much lower than 50 percent, these journals were not treated as OA or even conditional OA journals.

We did not detect any journal title changes or journals that had merged with other titles within the sample between 2004 and 2008. So, the sample remained stable in these respects throughout the period of analysis.

Research articles that contained references were included after each individual article was manually examined on its original publication and cross-checked on the citation tool, while reviews, col- umns, reports, and similar contributions were excluded. Citation data of all journal articles were gathered from GS to make the assessment consistent and reliable. For the calculation of the $h$-indexes and related parameters, Publish or Perish, ${ }^{23}$ a software tool developed by Harzing, was used to extract citation data from GS. ${ }^{24}$ Using its journal impact analysis function, each journal's title was individually entered for calculation, and spelling variations (such as "and" and "\&"), as well as abbreviated and altered journal titles, were searched. Quotation marks were added as alternative searches. During the analysis of each journal, articles of the five years as returned by Publish or Perish were individually verified against the article list compiled previously. The major concern in the journal impact analysis was journals that had common words in their titles: for example, Library Quarterly might also return Public Library Quarterly. Several searching strategies were adopted to improve accuracy, such as excluding selected title words or deselecting irrelevant articles. Because the $h$-index provides a robust measure, insignificant inclusion of wrong articles would create very minimal impact on the results of an analysis, unless highly cited articles were missed or incorrectly presented. It is fortunate that such inaccuracies were easily fixed by careful manual inspections. The analysis was conducted in December of 2010.

\section{Findings}

\section{Strong Correlations between the h-indexes and Journal Impact Factors}

Table 2 lists correlations between the $h$ indexes and impact factors of LIS journals year by year. The impact factors are from JCR, and therefore only journals available in JCR are included. JCR added a small 
number of new journals and removed a few old journals during the period studied. The 2008 additions include Journal of the Association for Information Systems, Journal of Informetrics, and Library Hi Tech. New journals in 2007 include Health Information and Libraries Journal, Journal of Computer-Mediated Communication, Journal of Global Information Management, Learned Publishing, and Serials Review. In contrast, Canadian Journal of Information and Library Science, which was listed in the early years in JCR, did not appear in 2008 and 2007. Some journals were not available on the 2008 JCR list although they were ranked in 2009, such as International Journal of Computer-Supported Collaborative Learning and Information Technology $\mathcal{E}$ Management.

Except for 2004 (a moderate correlation found), the correlations between the $h$ indexes and impact factors of LIS journals are high, which indicate the reliability of the $h$-index evaluations at the journal level. This finding is consistent with the results of the other studies mentioned above, increasing confidence in using the $h$-index to position OA journals in the journal rankings.

Because the major databases that provide impact factors of LIS journals have been reluctant to include more OA journals in their rankings, researchers do not have a clear picture of the current academic status of OA publishing. Therefore, it will be good if citation data providers like the JCR can periodically introduce new OA journals that meet their ranking criteria, such as OA journals that serve a broad subject area with a large readership and authorship and that have been in practice for a certain period of time so that a scholarly reputation has been adequately established.

\section{Uneven Performance of OA Journals in the Ranking}

Of the 85 LIS journals studied, 27 are OA journals open to everyone without subscription requirements and eight are conditional OA journals with an embargo period of six months to three years; the OA journals thus total 42 percent of all the journals assessed. All but two of the OA journals (93 percent) are published in Europe and North America, as compared to 98 percent of the non-OA journals published in the two regions. As for the frequency of publications, there is no obvious difference between OA and nonOA journals.

Table 3 has a complete list of the LIS journals ranked using $h$-values. Several OA journals are ranked high in the list, notably Journal of Computer-Mediated Communication and Journal of Medical Internet Research in the top ten and The D-Lib Magazine at number 11 (Journal of Medical Internet Research is not listed as a LIS journal in JCR); these journals have a high $h$-index comparable to other traditionally top-ranked LIS journals. Because the $h$-index is very discipline-specific, some top journals that do not belong exactly to LIS, such as MIS Quarterly and Journal of Management Information Systems for business and International Journal of Geographic Information Science for geography, could be excluded from the ranking. OA journals would then increase their ranks by several positions. Some other OA journals are also ranked highly: Journal of the Medical Library Association, First Monday, Information Research, and Journal of Digital Information, all of which perform better than such reputable non-OA journals as Journal of Documentation, Journal of Information Science, and Library \& Information Science Research.

\begin{tabular}{|l|c|c|c|c|c|}
\hline \multicolumn{7}{|c|}{ TABLE 2} \\
Correlation Coefficients Between $\boldsymbol{h}$-indexes and Impact Factors of \\
LIS Journals \\
\hline & 2004 & 2005 & 2006 & 2007 & 2008 \\
\hline Coefficient $\boldsymbol{R}^{2}$ & 0.578 & 0.729 & 0.801 & 0.729 & 0.819 \\
\hline
\end{tabular}




\begin{tabular}{|c|c|c|c|c|}
\hline \multicolumn{5}{|c|}{$\begin{array}{c}\text { TABLE } 3 \\
\text { LIS OA (Italic) and non-OA journals Ranked by } h \text {-index }\end{array}$} \\
\hline Rank & Journal & $h$-index & OA Status & JCR* \\
\hline 1 & Information \& Management & 62 & Non-OA & 6 \\
\hline 2 & MIS Quarterly & 60 & Non-OA & 1 \\
\hline 3 & $\begin{array}{l}\text { Journal of the American Medical Informatics } \\
\text { Association }\end{array}$ & 54 & Non-OA & 2 \\
\hline 4 & $\begin{array}{l}\text { Journal of the American Society for Information } \\
\text { Science and Technology }\end{array}$ & 49 & Non-OA & 12 \\
\hline 5 & Journal of Computer-Mediated Communication & 44 & $\mathrm{OA}$ & 14 \\
\hline 5 & Journal of Management Information Systems & 44 & Non-OA & 6 \\
\hline 7 & Information Processing \& Management & 43 & Non-OA & 15 \\
\hline 8 & Scientometrics & 41 & Non-OA & 8 \\
\hline 9 & Journal of Medical Internet Research & 37 & $\mathrm{OA}$ & $* *$ \\
\hline 10 & $\begin{array}{l}\text { International Journal of Geographical Information } \\
\text { Science }\end{array}$ & 34 & Non-OA & 20 \\
\hline 11 & D-Lib Magazine & 33 & $\mathrm{OA}$ & $\mathrm{n} / \mathrm{a}$ \\
\hline 12 & Journal of Health Communication & 32 & Non-OA & 10 \\
\hline 13 & $\begin{array}{l}\text { Journal of the Association for Information } \\
\text { Systems }\end{array}$ & 29 & Non-OA & 16 \\
\hline 13 & Telecommunications Policy & 29 & Non-OA & 22 \\
\hline 15 & Information Systems Journal & 28 & Non-OA & 5 \\
\hline 15 & International Journal of Information Management & 28 & Non-OA & 26 \\
\hline 17 & Information Society & 27 & Non-OA & 27 \\
\hline 17 & Journal of the Medical Library Association & 27 & $\mathrm{OA}$ & 18 \\
\hline 19 & Government Information Quarterly & 26 & Non-OA & 13 \\
\hline 20 & First Monday & 25 & $\mathrm{OA}$ & $\mathrm{n} / \mathrm{a}$ \\
\hline 21 & $\begin{array}{l}\text { Annual Review of Information Science and } \\
\text { Technology }\end{array}$ & 24 & Non-OA & 4 \\
\hline 21 & $\begin{array}{l}\text { Information Research - An International } \\
\text { Electronic Journal }\end{array}$ & 24 & $\mathrm{OA}$ & 28 \\
\hline 21 & Journal of Digital Information & 24 & $\mathrm{OA}$ & $\mathrm{n} / \mathrm{a}$ \\
\hline 21 & Journal of Information Technology & 24 & Non-OA & 11 \\
\hline 25 & Journal of Academic Librarianship & 23 & Non-OA & 35 \\
\hline 25 & Journal of Documentation & 23 & Non-OA & 17 \\
\hline 25 & Social Science Computer Review & 23 & Non-OA & 32 \\
\hline 28 & $\begin{array}{l}\text { International Journal of Computer-Supported } \\
\text { Collaborative Learning }\end{array}$ & 22 & $\mathrm{OA}$ & $\mathrm{n} / \mathrm{a}$ \\
\hline 28 & Journal of Information Science & 22 & Non-OA & 19 \\
\hline 30 & Library \& Information Science Research & 21 & Non-OA & 23 \\
\hline 31 & Information Technology \& Management & 20 & Non-OA & $\mathrm{n} / \mathrm{a}$ \\
\hline
\end{tabular}




\begin{tabular}{|c|c|c|c|c|}
\hline \multicolumn{5}{|c|}{$\begin{array}{c}\text { TABLE } 3 \\
\text { LIS OA (Italic) and non-OA journals Ranked by } h \text {-index }\end{array}$} \\
\hline Rank & Journal & $h$-index & OA Status & JCR* \\
\hline 32 & College \& Research Libraries*** & 19 & Conditional & 31 \\
\hline 32 & Health Information and Libraries Journal & 19 & Conditional & 30 \\
\hline 32 & Journal of Global Information Management & 19 & Non-OA & 21 \\
\hline 32 & Online Information Review & 19 & Non-OA & 25 \\
\hline 36 & Information Systems Research & 18 & Non-OA & 9 \\
\hline 36 & Journal of Informetrics & 18 & Non-OA & 3 \\
\hline 38 & ASLIB Proceedings & 17 & Non-OA & 38 \\
\hline 38 & Reference Services Review & 17 & Non-OA & $\mathrm{n} / \mathrm{a}$ \\
\hline 40 & Learned Publishing & 16 & Conditional & 37 \\
\hline 40 & Library Hi Tech & 16 & Non-OA & 50 \\
\hline 40 & Library Trends & 16 & Non-OA & 56 \\
\hline 40 & portal - Libraries and the academy & 16 & Non-OA & 24 \\
\hline 44 & Information Technology and Libraries & 15 & Conditional & 33 \\
\hline 44 & Research Evaluation & 15 & Conditional & 28 \\
\hline 46 & Ariadne & 13 & OA & $\mathrm{n} / \mathrm{a}$ \\
\hline 46 & Law Library Journal & 13 & $\mathrm{OA}$ & 53 \\
\hline 46 & Reference \& User Services Quarterly & 13 & $\mathrm{OA}$ & 52 \\
\hline 46 & Serials Review & 13 & Non-OA & 45 \\
\hline 50 & Electronic Journal of Knowledge Management & 11 & $\mathrm{OA}$ & $\mathrm{n} / \mathrm{a}$ \\
\hline 50 & Electronic Library & 11 & Non-OA & 43 \\
\hline 50 & $\begin{array}{l}\text { Program: Electronic Library and Information } \\
\text { Systems }\end{array}$ & 11 & Non-OA & 54 \\
\hline 50 & Social Science Information & 11 & Non-OA & 51 \\
\hline 54 & Interlending \& Document Supply & 10 & Non-OA & 39 \\
\hline 54 & International Information \& Library Review & 10 & Non-OA & $\mathrm{n} / \mathrm{a}$ \\
\hline 54 & Journal of Librarianship and Information Science & 10 & Non-OA & 36 \\
\hline 54 & $\begin{array}{l}\text { Library Collections Acquisitions \& Technical } \\
\text { Services }\end{array}$ & 10 & Non-OA & 46 \\
\hline 54 & LIBRI & 10 & Conditional & 58 \\
\hline 59 & $\begin{array}{l}\text { Informing Science The International Journal of } \\
\text { an Emerging Transdiscipline }\end{array}$ & 9 & $\mathrm{OA}$ & $\mathrm{n} / \mathrm{a}$ \\
\hline 59 & Journal of Knowledge Management Practice & 9 & $\mathrm{OA}$ & $\mathrm{n} / \mathrm{a}$ \\
\hline 59 & Knowledge Organization & 9 & Non-OA & 41 \\
\hline 59 & Library Quarterly & 9 & Non-OA & 46 \\
\hline 63 & American Archivist & 8 & Conditional & $\mathrm{n} / \mathrm{a}$ \\
\hline 63 & $\begin{array}{l}\text { Journal of Education for Library \& Information } \\
\text { Science }\end{array}$ & 8 & Non-OA & $\mathrm{n} / \mathrm{a}$ \\
\hline
\end{tabular}




\begin{tabular}{|c|c|c|c|c|}
\hline \multicolumn{5}{|c|}{$\begin{array}{c}\text { TABLE } 3 \\
\text { LIS OA (Italic) and non-OA journals Ranked by } h \text {-index }\end{array}$} \\
\hline Rank & Journal & $h$-index & OA Status & JCR* \\
\hline 63 & Library Philosophy and Practice & 8 & $\mathrm{OA}$ & $\mathrm{n} / \mathrm{a}$ \\
\hline 63 & Library Resources \& Technical Services & 8 & Conditional & 34 \\
\hline 63 & Webology & 8 & $\mathrm{OA}$ & $\mathrm{n} / \mathrm{a}$ \\
\hline 68 & $\begin{array}{l}\text { Canadian Journal of Information and Library } \\
\text { Science }\end{array}$ & 7 & Non-OA & 61 \\
\hline 68 & Cybermetrics & 7 & $\mathrm{OA}$ & $\mathrm{n} / \mathrm{a}$ \\
\hline 68 & International Journal of Legal Information & 7 & $\mathrm{OA}$ & $\mathrm{n} / \mathrm{a}$ \\
\hline 68 & Issues in Science and Technology Librarianship & 7 & $\mathrm{OA}$ & $\mathrm{n} / \mathrm{a}$ \\
\hline 72 & Collection Management & 6 & Non-OA & $\mathrm{n} / \mathrm{a}$ \\
\hline 72 & International Review of Information Ethics & 6 & $\mathrm{OA}$ & $\mathrm{n} / \mathrm{a}$ \\
\hline 72 & Journal of Electronic Publishing & 6 & $\mathrm{OA}$ & $\mathrm{n} / \mathrm{a}$ \\
\hline 72 & Journal of Information Ethics & 6 & Non-OA & $\mathrm{n} / \mathrm{a}$ \\
\hline 72 & Journal of Scholarly Publishing & 6 & Non-OA & 40 \\
\hline 72 & Restaurator & 6 & Non-OA & 57 \\
\hline 72 & $\begin{array}{l}\text { The Electronic Journal of Academic and Special } \\
\text { Librarianship }\end{array}$ & 6 & $\mathrm{OA}$ & $\mathrm{n} / \mathrm{a}$ \\
\hline 79 & Libraries \& Culture & 5 & Non-OA & $\mathrm{n} / \mathrm{a}$ \\
\hline 79 & School Library Media Research & 5 & $\mathrm{OA}$ & $\mathrm{n} / \mathrm{a}$ \\
\hline 81 & Information Technology and Disabilities & 4 & $\mathrm{OA}$ & $\mathrm{n} / \mathrm{a}$ \\
\hline 81 & Microform \& Imaging review & 4 & Non-OA & $\mathrm{n} / \mathrm{a}$ \\
\hline 83 & LIBRES & 3 & $\mathrm{OA}$ & $\mathrm{n} / \mathrm{a}$ \\
\hline 83 & $\begin{array}{l}\text { South African Journal of Information } \\
\text { Management }\end{array}$ & 3 & $\mathrm{OA}$ & $\mathrm{n} / \mathrm{a}$ \\
\hline 85 & $\begin{array}{l}\text { Electronic Journal of Information Systems in } \\
\text { Developing Countries }\end{array}$ & 2 & $\mathrm{OA}$ & $\mathrm{n} / \mathrm{a}$ \\
\hline \multicolumn{5}{|c|}{$\begin{array}{l}\text { * JCR ranking by impact factors in } 2008 \text { for the purpose of comparison only } \\
\text { ** Not listed as a LIS journal in JCR } \\
\text { *** College \& Research Libraries became an OA journal from Spring } 2011 .\end{array}$} \\
\hline
\end{tabular}

Not only are some OAjournals ranked among the top LIS journals by JCR, but their $h$-values are also very high. For example, the $h$-indexes of Journal of Computer-Mediated Communication, Journal of Medical Internet Research, and The D-Lib Magazine are 44, 37, and 33 respectively. Comparatively, some traditionally prestigious non-OA journals, such as Library Trends, portal: Libraries and the Academy, and Journal of Librarianship and Information Science, have $h$-values as low as 16,16, and 10 , respectively.
Around one-third of the OA journals are in the middle range of the ranking; eight journals have $h$-indexes between 10 and 25. Nonetheless, more than half of the OA journals ( 15 journals) appear at the bottom of the list with $h$-indexes lower than ten. Many of these least influential journals serve special groups with either a relatively small number of researchers or for mostly non-English researchers. Examples include Information Technology and Disabilities and Electronic Journal of Information Systems in Developing Coun- 
tries with $h$-indexes as low as 4 and 2 respectively.

\section{Journals Born $\mathrm{OA}$ or Converted into $\mathrm{OA}$}

Journals are born-OA if they originated in a digital form and were initially designed for open access. Typically, born-OA journals do not deliver print editions. Among others, The D-Lib Magazine, First Monday, and Information Research belong to this category. In contrast, some journals have a history of restricted access but converted to OA in recent years. Some of these journals offer an online companion to the print version, such as Reference $\mathcal{E}$ User Services Quarterly; the rest digitize their archived issues for free access or provide article preprints, such as College $\mathcal{E}$ Research Libraries (which became an OA journal in spring 2011). The American Library Association (ALA) has played an active role in converting its journals to OA or conditional OA. In addition to the two examples listed above, the ALA also changed Information Technology and Libraries and Library Resources \& Technical Services to conditional OA journals. More studies are needed to explore whether such an OA conversion has actually brought more citations to these publications.

\section{Discussion}

\section{OA Journal Ranking}

As mentioned above, the $h$-index is discipline-dependent. ${ }^{25}$ Comparing journal productivity and citation practices from different academic fields using the $h$-index can be questionable. This study includes some non-LIS journals traditionally included in JCR's ranking for the purpose of comparing $h$-values and journal impact factors but does not exclude them from the $h$-index based journal ranking. Most of such journals have a high $h$ value because of their different readership. Readers should be aware of the limitation and interpret this ranking accordingly.

New journals are potentially disadvantaged in an $h$-index analysis because the duration of journal publication can affect the ranking. This study set a five-year citation window to assess selected LIS journals. An effort has been made to select OA journals that started publication no later than 2004. Yet there are exceptions for non-OA journals or even for OA journals traditionally on the JCR list. For example, Journal of Informetrics, one of the higher ranked journals by impact factors in JCR, was first published in 2007. With only two years of citation data in this analysis, its relatively low $h$-value (18) is unsurprising, although its impact factor based on a two-year accumulation of citations is very high. It is fortunate that such exceptions are few and do not significantly change the overall journal ranking.

With $h$-index analyses, "a journal that publishes a larger number of papers has a higher likelihood of generating a higher $h$-index, ${ }^{\prime 26}$ which present a similar problem in citation analyses based on impact factors. This is partly because journals publishing more articles tend to serve wider readerships, thereby attracting more citations. In this ranking, the toprated journals published more issues on average than the bottom-rated journals. Hypothetically, OA journals are flexible in accommodating a large number of lengthy publications and can receive more article downloads, consequently collecting more citations than access-restricted journals. Nonetheless, the ranking, with many OA journals at the bottom, indicates that the number of articles published in a journal may be determined by the laws of supply and demand of articles and authors, if factors such as the history, editorship, and management style of the journal are not taken into consideration.

Time does not seem to be an important factor affecting the ranking of OA journals. The majority of OA journals selected for the analysis have been published for around ten years. Some have developed scholarly prestige in the short publication period, but others have not been so successful. Although both Journal of Computer-Mediated Communication and LIBRES started their business in the mid- 
1990s, their $h$-values are in sharp contrast (44 versus 3).

\section{OA Journals and Library Publishing}

In recent years, there have been an increasing number of academic libraries that became involved in journal publishing as a new direction of supporting open access scholarly communication. ${ }^{27}$ The Association of Research Libraries published a report that surveyed eighty research libraries in the United States and found that as high as about 65 percent of these libraries had already provided publishing services or were at the stage of planning such services. ${ }^{28}$ Nearly 88 percent of these publishing services published peer-reviewed OA journals. With many smaller universities and colleges having lately joined the effort, the number of library publications must be much higher. ${ }^{29}$

While a promising step toward supporting OA journal publishing, academic libraries have faced many challenges in practice, including concerns on applicability, sustainability, and scalability of providing such services. ${ }^{30}$ The primary challenge that most libraries have had is how to make their journals scholarly recognizable. This OA journal ranking has been able to list several OA journals as the top-ranked ones in the field, some of which are the products of library publishing such as First Monday by the University of Illinois at Chicago Library. It will be worthwhile to further investigate how OA journals born from practitioner sites rather than from for-profit publishers reflect the growth practitioner knowledge in librarianship. This ranking allows library practitioners to identify the successful services and learn from the valuable experience of the high-ranked OA journals.

Open access has been in place for more than two decades. It has created a positive impact on the citation rate of journal articles. The majority of studies on this topic have discovered a citation advantage of free publications, although a few scholars have argued that factors other than open access might have also influenced the patterns of citation. ${ }^{31}$ LIS is one of the academic fields where a considerable number of OA journals have been created, and many authors have enthusiastically contributed to the OA effort. Similar academic disciplines with a scholarly tradition of free and wide information sharing have also observed prosperity in OA publishing and an OA advantage in supporting research, such as physics and computer engineering. ${ }^{32}$ Academic culture has played an important role in the innovation of scholarly communication.

However, it should be noted that an increase in the number of citations and OA journal publishing may be a reflection of the larger open access movement. Scholars in other fields such as the humanities and social sciences where free information sharing is not a common practice have become more aware of the value of open access, more willing to participate in self-archiving, and already more involved in various OA activities. ${ }^{33}$ In LIS, librarians have been among the driving forces behind open access. They now need to expand their services to other fields and help them in the design of more systematic and consistent OA strategies.

\section{Conclusion}

OA journals have gained momentum supporting high-quality research and publication. An $h$-index analysis for journal ranking has appraised the value of OA journals in the field of library and information science. Several OA journals have been rated as high as the best traditional non-OA journals. Considering the relatively short history of the open access movement, the achievements of these OA journals are not exaggerated. This encouraging news is good for the ongoing promotion of the new means of digital scholarly communication among researchers. The $h$-index method could also be applied to other disciplines, which promises a richer comparative analysis of publishing trends among the applied 
social sciences in the future as the OA movement continues to evolve.

At the same time, there is a large group of OA journals rated poorly in the $h$-index ranking. No matter what causes are behind their citation conditions, it indicates that open access has a long way to go. The awareness and willingness of scholars to participate in OA is still a challenge for librarians and information professionals, who need to develop better approaches to improve the standing of OA journals. The successful stories of the top-ranked OA journals may provide some good examples.

\section{Notes}

1. Budapest Open Access Initiative, available online at www.soros.org/openaccess/read.shtml [accessed 1 May 2011].

2. Stevan Harnad, "OA, OA Self-Archiving, OA Publishing, and Data Archiving," Open Access Archivangelism (Oct. 2010), available online at http://openaccess.eprints.org/index.php?/ categories/19-Definition-of-Open-Access [accessed 1 May 2011]; Sara Schroter and Leanne Tite, "Open Access Publishing and Author-Pays Business Models: A Survey of Authors' Knowledge and Perceptions," The Royal Society of Medicine 99, no. 3 (Mar. 1999): 141-48.

3. Alma Swan and Leslie Chan, "Converting to Open Access," OASIS (Feb. 2009), available online at www.openoasis.org/index.php?option=com_content\&view=article\&id=357\&Itemid=380 [accessed 1 May 2011].

4. Thomson Reuters (Institute for Scientific Information), Journal Citation Reports, available online at http://science.thomsonreuters.com/training/jcr [accessed 29 December 2010].

5. Bhaskar Mukherjee, "Do Open-Access Journals in Library and Information Science Have Any Scholarly Impact? A Bibliometric Study of Selected Open-Access Journals Using Google Scholar," Journal of the American Society for Information Science and Technology 60, no. 3 (Mar. 2009): 581-94; Bhaskar Mukherjee, "The Hyperlinking Pattern of Open-Access Journals in Library and Information Science: A Cited Citing Reference Study," Library \& Information Science Research 31, no. 2 (Apr. 2009): 113-25.

6. Bhaskar Mukherjee, “Do Open-Access Journals in Library and Information Science Have Any Scholarly Impact?" 591.

7. Lokman I. Meho and Kiduk Yang, "Impact of Data Sources on Citation Counts and Rankings of LIS Faculty: Web of Science vs. Scopus and Google Scholar," Journal of the American Society for Information Science and Technology 58, no. 13 (Nov. 2007): 2105-25.

8. Kiduk Yang and Lokman I. Meho, "Citation Analysis: A Comparison of Google Scholar, Scopus, and Web of Science," in Information Realities: Shaping the Digital Future for All: Proceedings of the Annual Meeting of the American Society for Information Science and Technology, eds. Andrew Dillon and A. Grove (Silver Springs, Md.: American Society for Information Science and Technology, 2006): 3-8.

9. Kathleen Bauer and Nisa Bakkalbasi, "An Examination of Citation Counts in a New Scholarly Communication Environment," D-Lib Magazine 11, no. 9 (Sept. 2005), available online at www.dlib.org/dlib/september05/bauer/09bauer.html [accessed 29 December 2010]; Richard K. Belew, "Scientific Impact Quantity and Quality: Analysis of Two Sources of Bibliographic Data," available online at http://arxiv.org/PS_cache/cs/pdf/0504/0504036v1.pdf [accessed 29 December 2010]; Jeroen Bosman, Ineke van Mourik, Menno Rasch, Eric Sieverts, and Huib Verhoeff, Scopus Reviewed and Compared: The Coverage and Functionality of the Citation Database Scopus, Including Comparisons with Web of Science and Google Scholar (Utrecht, Netherlands: Utrecht University Library, 2006), available online at http://igitur-archive.library.uu.nl/DARLIN/2006-1220-200432/ Scopus doorgelicht \& vergeleken - translated.pdf [accessed 29 December 2010]; Liwen Vaughan and Debora Shaw, "A New Look at Evidence of Scholarly Citations in Citation Indexes and from Web Sources," Scientometrics 74, no. 2 (2008): 317-30.

10. Alireza Noruzi, "Google Scholar: The New Generation of Citation Indexes," LIBRI 55, no. 4 (Dec. 2005): 170-80.

11. Kayvan Kousha and Mike Thelwall, "Motivations for URL Citations to Open Access Library and Information Science Articles," Scientometrics 68, no. 3 (2006): 50-57; Michael Norris, Charles Oppenheim, and Fytton Rowland, "Finding Open Access Articles Using Google, Google Scholar, OAIster and Open DOAR," Online Information Review 32, no. 6 (2008): 709-15.

12. Judit Bar-Ilan, "Which $h$-Index? A Comparison of WoS, Scopus and Google Scholar," Scientometrics 74, no. 2 (Nov. 2008): 257-71; Kayvan Kousha and Mike Thelwall, "Google Scholar Citations and Google Web/URL Citations: A Multidiscipline Exploratory Analysis," Journal of 


\section{Positioning Open Access Journals in a LIS Journal Ranking 145}

the American Society for Information Science and Technology 58, no.7 (May 2007): 1055-65; Kayvan Kousha and Mike Thelwall, "Sources of Google Scholar Citations Outside the Science Citation Index: A Comparison between Four Science Disciplines," Scientometrics 74, no. 2 (2008): 273-94.

13. Anne-Wil K. Harzing and Ron van der Wal, "A Google Scholar $h$-Index for Journals: An Alternative Metric to Measure Journal Impact in Economics and Business," Journal of the American Society for Information Science and Technology 60, no. 1 (Sept. 2008): 41-46; Anne-Wil K. Harzing and Ron van der Wal, "Google Scholar as a New Source for Citation Analysis," Ethics in Science and Environmental Politics 8 (June 2008): 61-73; Daniel Pauly and Konstantinos L. Stergiou, “Equivalence of Results from Two Citation Analyses: Thomson ISI's Citation Index and Google Scholar's Service," Ethics in Science and Environmental Politics (Dec. 2005): 33-35.

14. Wolfgang Glänzel, "On the Opportunities and Limitations of the $h$-Index," Science Focus 1, no. 1 (2006): 10-11; J.E. Hirsch, "An Index to Quantify an Individual's Scientific Research Output," available online at http://arxiv.org/PS_cache/physics/pdf/0508/0508025v5.pdf [accessed 29 December 2010]; Gad Saad, "Exploring the $h$-Index at the Author and Journal Levels Using Bibliometric Data of Productive Consumer Scholars and Business-Related Journals Respectively," Scientometrics 69, no. 1 (2006): 117-20.

15. Blaise Cronin and Lokman I. Meho, "Using the $h$-Index to Rank Influential Information Scientists," Journal of the American Society for Information Science and Technology 57, no. 9 (May 2006): 1277.

16. Harzing and van der Wal, "A Google Scholar $h$-Index for Journals," 43.

17. Tibor Braun, Wolfgang Glänzel, and András Schubert, "A Hirsch-type Index for Journals," Scientometrics 69, no. 1 (2006): 169-73.

18. David R. Hodge and Jeffrey R. Lacasse, "Evaluating Journal Quality: Is the $h$-Index a Better Measure than Impact Factors?" Research on Social Work Practice 21, no. 2 (Mar. 2011): 222-30.

19. Harzing and van der Wal, "A Google Scholar $h$-Index for Journals."

20. Somnath Saha, Sanjay Saint, and Dimitri A. Christakis, "Impact Factor: A Valid Measure of Journal Quality?" Journal of Medical Library Association 91, no. 1 (Jan. 2003): 42-46.

21. Thomas E. Nisonger and Charles H. Davis, "The Perception of Library and Information Science Journals by LIS Education Deans and ARL Library Directors: A Replication of the KohlDavis Study," College \& Research Libraries 66, no. 4 (July 2005): 341-77.

22. Directory of Open Access Journals, available online at www.doaj.org [accessed 29 December 2010].

23. Anne-Wil K. Harzing, Publish or Perish (2010), v. 3.1.4004, available at www.harzing.com/ pop.htm [accessed 1 May 2011].

24. Harzing and van der Wal, "A Google Scholar $h$-Index for Journals."

25. Rodrigo Costas and María Bordons, "The $h$-Index: Advantages, Limitations and its Relation with Other Bibliometric Indicators at the Micro Level," Journal of Informetrics 1 (2007): 193-203.

26. Harzing and van der Wal, "A Google Scholar $h$-Index for Journals," 42.

27. Jean-Gabriel Bankier and Courtney Smith, "Establishing Library Publishing: Best Practices for Creating Successful Journal Editors," Proceedings ELPUB 2008 Conference on Electronic Publishing (Toronto, 2008): 68-78; Jingfeng Xia, "Library Publishing as a New Model of Scholarly Communication," Journal of Scholarly Publishing 40, no. 4 (July 2009): 370-83.

28. Karla L. Hahn, Research Library Publishing Services: New Options for University Publishing (Washington, D.C.: Association of Research Libraries, 2008).

29. Jean-Gabriel Bankier and Irene Perciali, “The Institutional Repository Rediscovered: What Can a University Do for Open Access Publishing?" Serials Review 34, no. 1 (Mar. 2008): 21-26.

30. Jean-Gabriel Bankier, Connie Foster, and Glen Wiley, "Institutional Repositories: Strategies for the Present and Future," The Serials Librarian 56, no. 1-4 (Jan. 2009): 109-15.

31. Philip M. Davis, "Studies on Access: A Review," available online at http://arxiv.org/ abs/0912.3953 [accessed 1 May 2011].

32. Yassine Gargouri, Chawki Hajjem, Vincent Larivière, Yves Gingras, Les Carr, Tim Brody, and Stevan Harnad, "Self-Selected or Mandated, Open Access Increases Citation Impact for Higher Quality Research," PlosONE 5, no. 10 (Jan. 2010), available online at www.plosone.org/ article/info:doi\%2F10.1371\%2Fjournal.pone.0013636 [accessed 1 May 2011]; Stevan Harnad and Tim Brody, "Comparing the Impact of Open Access (OA) vs. Non-OA Articles in the Same Journals," D-Lib Magazine 10, no. 6 (June 2004), available online at www.dlib.org/dlib/june04/ harnad/06harnad.html [accessed 1 May 2011].

33. Christopher M. Kelty, Michael M.J. Fischer, Alex Golub, Jason Baird Jackson, Kimberly Christen, Michael Brown, and Tom Boellstorff, "Anthropology of/in Circulation: The Future of Open Access and Scholarly Societies," Cultural Anthropology 23, no. 3 (July 2008): 559-88. 


\section{acrl 2013 \\ peer revered \\ APRIL 10-13 \\ Indianapolis, Indiana \\ Call for Participation \\ www.acrl.org/acrlconference}

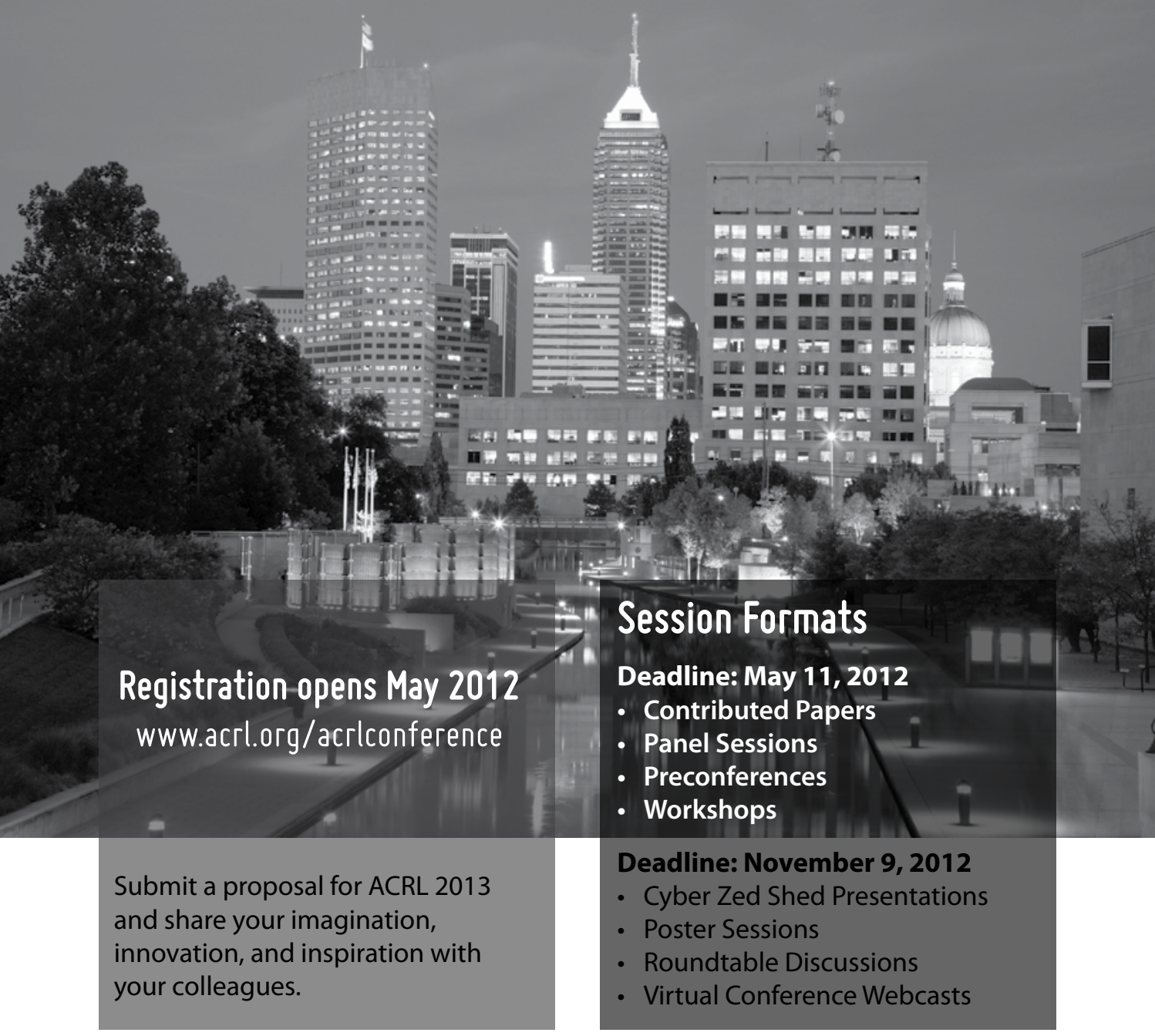
\& Research Libraries A Division of the American Library Associaton
50 E. Huron, Chicago IL 60611 |1.800.545.2433

www.acrl.org | acrl@ala.org 